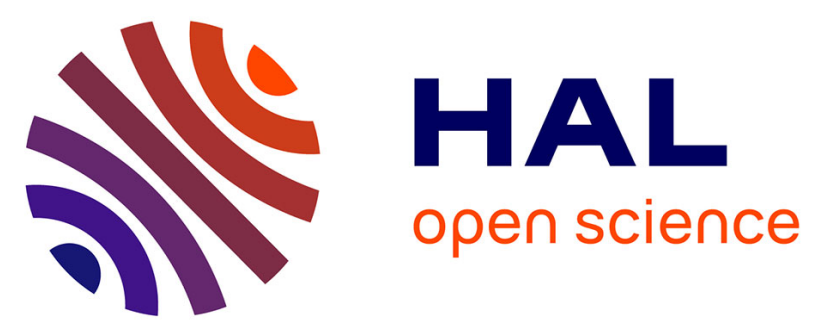

\title{
eGY-Africa: Addressing the digital divide for science in Africa
}

C. E. Barton, Christine Amory-Mazaudier, B. Barry, V. Chukwuma, R.L. Cottrell, U. Kalim, A. Mebrahtu, Monique Petitdidier, B. Rabiu, C. Reeves

\section{- To cite this version:}

C. E. Barton, Christine Amory-Mazaudier, B. Barry, V. Chukwuma, R.L. Cottrell, et al.. eGYAfrica: Addressing the digital divide for science in Africa. Russian Journal of Earth Science, 2009, 11, pp.ES1003. 10.2205/2009ES000377 . hal-00966469

\section{HAL Id: hal-00966469 https://hal.sorbonne-universite.fr/hal-00966469}

Submitted on 26 Mar 2014

HAL is a multi-disciplinary open access archive for the deposit and dissemination of scientific research documents, whether they are published or not. The documents may come from teaching and research institutions in France or abroad, or from public or private research centers.
L'archive ouverte pluridisciplinaire HAL, est destinée au dépôt et à la diffusion de documents scientifiques de niveau recherche, publiés ou non, émanant des établissements d'enseignement et de recherche français ou étrangers, des laboratoires publics ou privés. 


\title{
RUSSIAN JOURNAL OF EARTH SCIENCES, VOL. 11, ES1003, doi:10.2205/2009ES000377, 2009 \\ PROCEEDINGS OF THE INTERNATIONAL CONFERENCE Electronic Geophysical Year: State of the Art and Results
}

3-6 June $2009 \bullet$ Pereslavl-Zalessky, Russia

\section{eGY-Africa: Addressing the digital divide for science in Africa}

\author{
C. E. Barton, ${ }^{1}$ C. Amory-Mazaudier, ${ }^{2}$ B. Barry, ${ }^{3}$ V. Chukwuma, ${ }^{4}$ R. L. Cottrell, ${ }^{5}$ U. Kalim, ${ }^{6}$ \\ A. Mebrahtu, ${ }^{7}$ M. Petitdidier,${ }^{8}$ B. Rabiu, ${ }^{9}$ and C. Reeves ${ }^{10}$ \\ Received 30 October 2009; accepted 6 November 2009; published 24 November 2009.
}

KEYWORDS: eGY-Africa, digital divide, Internet services, cyber-infrastructure, science in Africa.

Citation: Barton, C. E., C. Amory-Mazaudier, B. Barry, V. Chukwuma, R. L. Cottrell, U. Kalim, A. Mebrahtu, M. Petitdidier, B. Rabiu, and C. Reeves (2009), eGY-Africa: Addressing the digital divide for science in Africa, Russ. J. Earth. Sci., 11, ES1003, doi:10.2205/2009ES000377.

\begin{abstract}
Adoption of information and communication technologies and access to the Internet is expanding in Africa, but because of the rapid growth elsewhere, a Digital Divide between Africa and the rest of the world exists, and the gap is growing. In many sub-Saharan African countries, education and research sector suffer some of the worst deficiencies in access to the Internet, despite progress in development of NRENs - National Research and Education (cyber) Networks. By contrast, it is widely acknowledged in policy statements from the African Union, the UN, and others that strength in this very sector provides the key to meeting and sustaining Millennium Development Goals. Developed countries with effective cyber-capabilities proclaim the benefits to rich and poor alike arising from the Information Revolution. This is but a dream for many scientists in African

\footnotetext{
${ }^{1}$ Research School of Earth Sciences, Australian National University, Canberra, Australia

${ }^{2}$ Laboratoire de Physique des Plasmas, 4 Avenue de Neptune, Saint Maur des Fosses, Cedex, France

${ }^{3}$ Association of African Universities, P.O. Box 5744, Accra North, Ghana

${ }^{4}$ Department of Physics, Olabisi Onabanjo University, AgoIwoye, Ogun State, Nigeria

${ }^{5}$ SLAC National Accelerator Laboratory, Menlo Park, California, USA

${ }^{6}$ School of Electrical Engineering and Computer Sciences (SEECS), Pakistani National University of Sciences and Technology (NUST), Islamabad, Pakistan

${ }^{7}$ Physics Department, Mekelle University, Mekelle, Ethiopia

${ }^{8}$ Laboratoire d'Atmosphere, Milieux, Observations Spatiales, Velizy, France

${ }^{9}$ Centre for Space Research and Applications, Federal University of Technology, Akure, Nigeria

${ }^{10}$ Earthworks bv, Delft, The Netherlands
}

Copyright 2009 by the Russian Journal of Earth Sciences. http://elpub.wdcb.ru/journals/rjes/doi/2009ES000377.html institutions. As the world of science becomes increasingly Internet-dependent, so they become increasingly isolated. eGY-Africa is a bottom-up initiative by African scientists and their collaborators to try to reduce this Digital Divide by a campaign of advocacy for better institutional facilities. Four approaches are being taken. The present status of Internet services, problems, and plans are being mapped via a combination of direct measurement of Internet performance (the PingER Project) and a questionnaire-based survey. Information is being gathered on policy statements and initiatives aimed at reducing the Digital Divide, which can be used for arguing the case for better Internet facilities. Groups of concerned scientists are being formed at the national, regional levels in Africa, building on existing networks as much as possible. Opinion in the international science community is being mobilized. Finally, and perhaps most important of all, eGY-Africa is seeking to engage with the many other programs, initiatives, and bodies that share the goal of reducing the Digital Divide either as a direct policy objective, or indirectly as a means to an end, such as the development of an indigenous capability in science and technology for national development. The expectation is that informed opinion from the scientific community at the institutional, national, and international levels can be used to influence the decision makers and donors who are in a position to deliver better Internet capabilities.

\section{Introduction}

In the scientific world and many other domains we are seeing a rapid growth of federations of virtual teams - groups of people who work across space, time, and organizational boundaries. Links are provided by Information and Communication Technologies (ICT), and they can collaborate with a minimum of face-to-face interaction. The wide ex- 
pansion of computer networks, the Internet, and the World Wide Web are some of the main drivers accelerating the creation of applications, technologies, and systems that enable these virtual teams to communicate, collaborate, cooperate, share information and services, and learn. Such "e" activities (e-collaboration, e-learning, and so forth) involve not only technological but also social and psychological issues. Any kind of map of Internet performance shows that scientists in Africa, in general, are not able to partner in such virtual teams and activities due to a lack of ICT infrastructure.

Science and Technology (S\&T) and ICT are now widely recognised as key vectors for reducing poverty, ensuring socio-economic development, and reaching the Millennium Development Goals (http://www.un.org/millenniumgoals/). They are essential for the evolution towards a sustainable peaceful, integrated and prosperous continent, making Africa a full player of the global community. The Africa Science and Technology Consolidated Plan of Action, formulated by the New Partnership for Africa's Development (NEPAD http://www.nepad.org/2005/fr/home.php) and the African Union (AU), the creation of the African Ministerial Council on Science and Technology (AMCOST), and the African Regional Action Plan on the Knowledge Economy (ARAPKE), are recent examples of Africa's determination to rely on S\&T and ICT to achieve growth and development objectives.

Many initiatives from local, governmental, European, and international organisations promote, survey, and fund networking in Africa. International organizations, such as the International Telecommunications Union, UNESCO, the International Development research Centre (IDRC)'s reports on Promoting African Research and Education Networking (PAREN) play a role in the deployment of ICT in Africa. The European Commission has developed a cooperative forum on ICT research called EuroAfrica (http://www.euroafrica-ict.org/). Since 2007, EuroAfrica has organized 13 "Awareness" workshops in Sub-Saharan Africa and a first workshop in March 2009 in Brussels. A second workshop is being organized in Ethiopia in early 2010. In the European sixth (2002-2006) and seventh (2007-2013) framework Programme, FP6 and FP7 respectively, there have been calls to submit proposals to the European Union for ICT African funding. In the first call the number of African proposals submitted was very low. For the next calls the European Commission will provide support for the coordinators of proposals in order to increase their numbers.

A combination of both top-down support and bottom-up demand from user communities are needed for sustainable success of project initiatives. In recognition of this and the difficulty for universities and research organisations to participate in virtual teams, the Electronic Geophysical Year (eGY) programme, initiated by the International Union of Geodesy and Geophysics (IUGG) and devoted mainly to international co-operation for open access to data, has included a "bottom-up" initiative called eGY-Africa. The aim is to promote better cyber-infrastructure and reliable and less-expensive Internet facilities for universities and research institutions that cannot take advantage of the developments made by eGY. The role of eGY-Africa is to motivate and support African scientists by providing a focus and informa- tion source for them to be advocates at national, regional and international levels.

The second part of this paper describes eGY-Africa. The third part provides an overview of the status of Internet in Africa in general and, in particular in African universities, and projects. The fourth part is devoted to the emerging African geo-science research communities involved in several international and continental projects. These communities are important as users of the Internet for the benefit of their countries. The fifth part of the paper concerns some pilot experiences and perspectives.

\section{2. eGY-Africa}

\subsection{What is eGY-Africa}

eGY-Africa is a communal effort by scientists from Africa and elsewhere to improve Internet capabilities in African universities and other research and education institutions. eGY-Africa's strategy to achieve this is to (i) coordinate a network of national and international bodies and groups who share this objective, (ii) provide an information base and arguments to highlight the Digital Divide problem and the value of investing in a cyber-infrastructure for research and education, and (iii) influence decision-makers and providers who are in a position to take action to address the problem.

eGY-Africa was initiated as an (eGY) effort to reduce the Digital Divide, with cooperation from the International Heliophysical Year (IHY) community. The international scientific community supports and promotes eGY-Africa through the International Council for Science (ICSU) via its Regional Office for Africa in Pretoria and the ICSU Committee on Data for Science and Technology (CODATA). The main sponsors of eGY-Africa are the International Union of Geodesy \& Geophysics (IUGG) and the International Association of Geomagnetism \& Aeronomy (IAGA), with additional support from NASA, the Laboratory for Atmospheric and Space Physics, University of Colorado (LASP), and inkind support from several other institutions.

\subsection{Why eGY-Africa?}

We are living at the commencement of the information era, in which access to information and knowledge is increasingly becoming the key factor that distinguishes rich from poor societies. The availability of, and ready access to digital information and ICT determines whether a community can participate in the remarkable benefits of the information revolution. In the area of science and technology, participation in the information revolution is particularly effective in delivering benefits to Society. But participation is conditional on there being an ICT infrastructure that connects scientists, technologists, and educators to the world community and the vast resources of information and services that exist. The irony for communities that lack such an infras- 
tructure is that they are becoming increasingly marginalized instead of being empowered by modern developments.

In Africa, as in the rest of the world, Internet capabilities are improving. The problem is that the capabilities in other parts of the world are advancing much faster than in Africa. In the world of research and education, this Digital Divide problem is exacerbated by a rapid move towards Internetdependency. For example, libraries are moving away from storing printed information, and it is almost impossible today to register for a conference or participate in an international project without effective access to the Internet.

eGY-Africa grew out of a combination of frustration by African scientists at the growing difficulties they face trying to participate in mainstream modern research and education, and the hypocrisy of claims that the information revolution provides unprecedented benefits to rich and poor alike.

\subsection{Recommendations}

Recommendations for promoting better Internet access and cyber-infrastructure in African countries were elaborated in 2007 during an eGY-Africa meeting that took place during the International Heliophysical Year (IHY) workshop in Ethiopia, and another bottom-up initiative, "Sharing the Knowledge" conference in France. The IHY workshop attracted 103 scientists including 63 scientists from 20 African countries. The "Sharing the Knowledge" conference on "Internet and Grids in Africa" was attended by scientists from different disciplines, industrialists, members of Non-Governmental Organisations (NGOs), and a member of the European Commission to represent the EuroAfrica programme. The participants came from 8 African and 6 non-African countries.

A major result of those meetings was the interaction among the African participants, who mostly did not initially know one another. They expressed their difficulties and their vision via a set of observations and recommendations. Internet access in Africa is poor as a consequence of weak and restricted adoption of ICT technologies, despite multiple local, national, regional and continental initiatives.

- Internet and cyber-infrastructure in Africa needs to be at the same level as other regions of the world for the general population and, particularly, for university research and learning centres. This is fundamental for sharing information, knowledge, pedagogy, computing services, and human resources. It will also facilitate collaborations among African teams and allow them to play a role with other teams in international projects.

- High priority has to be given to improving the cyberinfrastructure for universities, colleges, and research organisations via NRENs. These NRENs should be interconnected at the regional level initially, then later at a continental level. The key words are reliability and cost-effectiveness. The performance of networks has to be monitored quantitatively. The PingER project [Matthews and Cottrell, 2000] was proposed to do this.
- While waiting for substantial improvements in Internet services and cyber-infrastructure, African participants want to strengthen the collaboration among African teams, create African networks of excellence that in turn are connected to worldwide networks, and experiment with new technologies at least at the local level.

\section{The Digital Divide in Africa}

\subsection{Context}

Different surveys have provided an overall view of the Internet situation in African countries and in their main towns. Internet conditions inside a university may differ greatly from this average. Cybercafes often have better Internet connectivity than the neighbouring university. In the Association of African Universities (AAU), the unit of Research and Education networking has initiatives to improve the situation. In general, the precise situation of Internet connectivity at the university level is not published, and may differ from one university to another in the same country as well as between different countries. Barry et al. 2008 analyzed Internet survey results for 2007 from 21 African universities in which geophysicists are collaborating in international programmes like IHY. These universities were in Algeria, Benin, Burkina Faso (2 responses), Cameroon, Congo Democratic Republic (RDC), Republic of Congo (RC), Egypt, Ethiopia, Kenya, Liberia, Libya, Mozambique, Niger, Nigeria, Senegal, South Africa (3 responses), Uganda. Among the results at that time the best connection had $2 \mathrm{Mbits} / \mathrm{s}$ Internet access to the outside world; the worst ones were using dial up at $56 \mathrm{kbps}$. To track the trends and measure the impact of new initiatives at the IHY Ethiopian meeting, the recommendations proposed to monitor the Internet performance, by using PingER, to at least one site per African country and to extend the number of monitoring stations in Africa.

In the following paragraphs we present the outputs of the eGY-Africa meeting in 2009 of the Internet conditions in Universities, we follow this by describing the monitoring of Internet performance by the PingER project and its results, and we give an overview of progress towards establishing NRENs. In 2007 less than 5 countries had an NREN.

\subsection{Outputs of the eGY-Africa Meeting During the IHY Workshop in 2009}

3.2.1. Internet situation. African universities can be the continent's gateways into the global information highway for ideas and local diffusion of new technologies. They are also the most critical links in international research cooperation. This is because most research in Africa is carried out in Africa's higher educational institutions and is entirely financed by government [Barry, 2008. Because of a lack of commitment on the part of governments, these research institutions suffer from dwindling resources (infrastructure, 


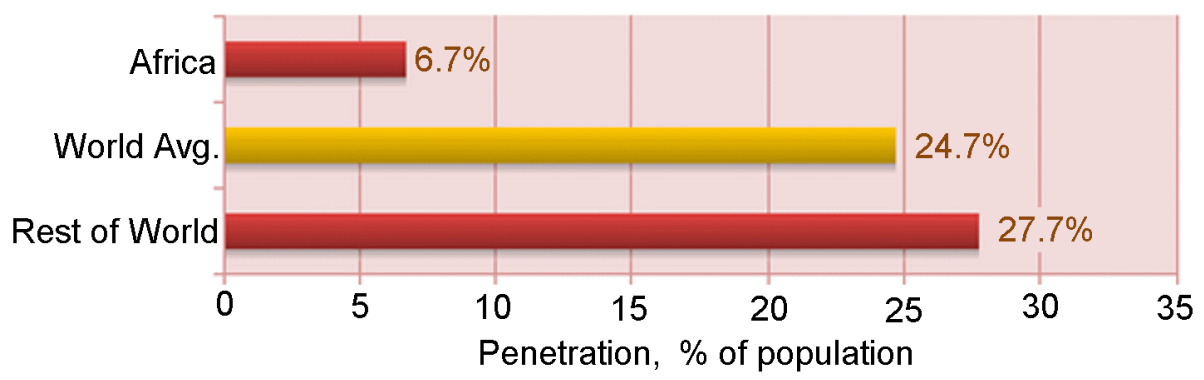

Figure 1. Internet Penetration in Africa 2009 Second Quarter. Source: Internet World Stats, March 2009 (http://www.internetworldstats.com).

equipment, finance, and other incentives). The consequences are the isolation of researchers and research teams, aging of facilities, and a brain drain.

Isolation and access to facilities and services can be alleviated by ICT and ready access to the Internet. But as shown in Figure 1 and Figure 2, Africa is confronted by problems of Internet penetration. Measurements covering $99 \%$ of the world's Internet-connected population shows that Africa is not only about 16 years behind the rest of the world, but is falling further behind each year [Barry et al. 2008. This rising Digital Divide between Africa and industrialized countries means that the potential of African universities to play a key role in national development is largely not being realized.

To decelerate and reverse the Digital Divide, eGY-Africa is growing partnerships with the many governments, global organizations, agencies, and consortia like GEANT, INTERNET2, and UbuntuNet [Duncan, 2008] Tusubira, 2008] that share this objective. The strategies of eGY-Africa are strongly recommended by [Barry, 2008] and [Tusubira, 2008. Recently, eGY-Africa used the platform created by the Open Forum on Infrastructure and Communication in Africa held at the IHY/SCINDA 2009 workshop in Livingstone, Zambia to make the presentation "Digital Divide, eGY-Africa, and the way forward" [Chukwuma et al., 2009]. The main points made during this presentation were:

- The process of deceleration and reversal of the Digital Divide is confronted with the problem of improving cyber infrastructure and bandwidth for universities and

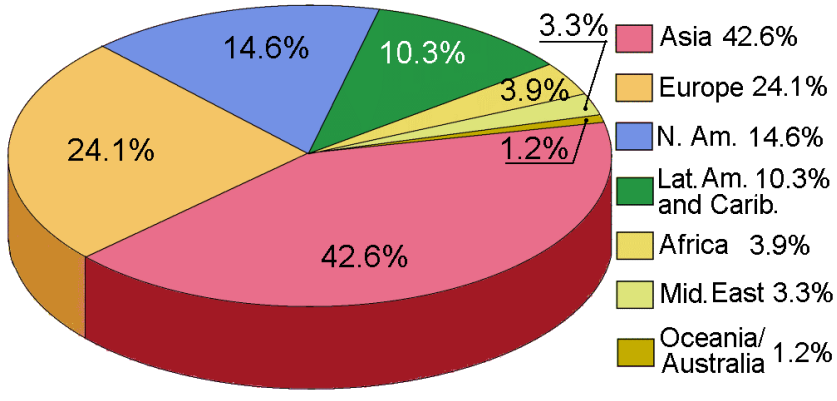

Figure 2. World Internet Users by World Regions. Source: Internet World Stats, 30 September 2009 (http://www.internetworldstats.com/stats.htm) other research and education institutes; these institutions are left to suffer the consequences of short-term market forces.

- Bandwidth costs for African universities are 50 times or higher than for universities in developed countries [Barry et al. 2008].

- Lack of reliable power supply in countries is a barrier to a reliable Internet functioning.

- As a solution, African scientists should initiate solutionoriented projects with identifiable goals that can create synergy which corporate organisations/Government can leverage on.

- Barry et al. 2008 recommends policy advocacy, collaboration between institutions, and formation of partnership between institutions and Internet Services Providers

3.2.2. Internet in Nigeria. The Nigerian backbone transmission infrastructure, developed by the MTN group and shown in Figure 3, consists of over 7,000 Km of microwave links and fibre optics cables that could be leveraged by eGY-Africa. The Nigerian Telecommunication company,

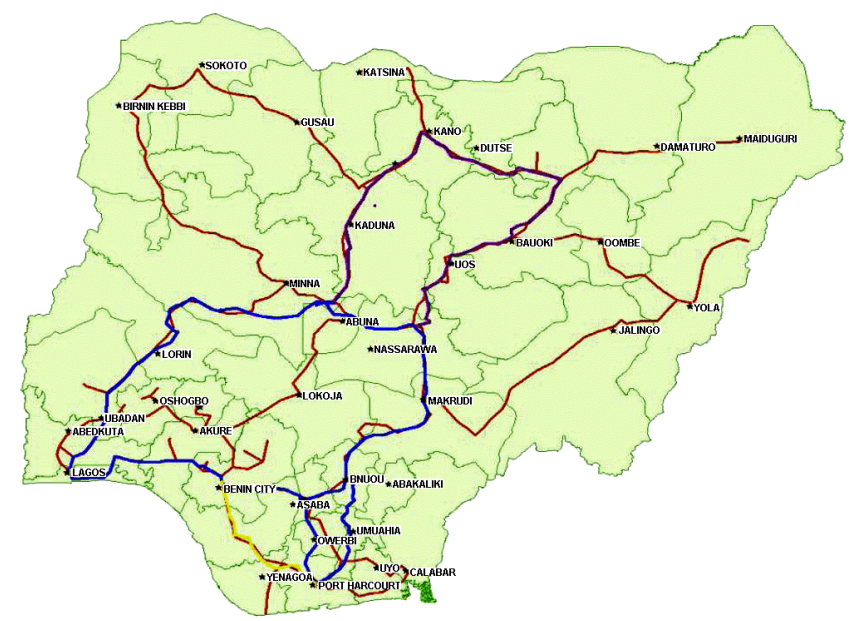

Figure 3. MTN Nigeria's national microwave and fibre optic transmission network. Source: [Chukwuma et al., 2009], courtesy of MTN Nigeria. 
Globacom, and another Telecommunication company, Zain, have also installed networks, in particular to connect nearly all University towns in Nigeria. The Nigerian NREN, NigREN, can leverage the infrastructure if the service providers see synergy in partnership The connection to other countries will be ensured by the Main-One Cable System of the Main Street Technologies (Nigerian sub-marine cable company). It will run 7000 kilometres from Portugal to Nigeria with branches to the Canary Islands, Morocco, Senegal, Ivory Coast and Ghana. The cable will deliver $1.92 \mathrm{Tbps}$ of bandwidth, equivalent to 10 times the available capacity of the existing fibre optics cable serving the West coast of Africa. The Main-One cable system will offer about 200 times the satellite capacity currently available across subSaharan Africa, and will operate on an open-access basis to telecoms, Internet, and data providers in West Africa.

3.2.3. Recommendations 2009. The Open Forum on Infrastructure and Communication in Africa generated the following suggestions and resolutions:

- eGY-Africa has provided support to a better cyberinfrastructure in Africa by advocacy in different international organisations, and recommendations to support local and national needs;

- A creation of an NGO (Non-Governmental Organisation) with strong private sector support and with the same objectives like eGY-Africa, was suggested in order to discuss with service providers and to work out strategies for synergistic partnership for individual countries;

- Importance to collaborate with NRENs and Regional Educational Networks (RENs), such as the UbuntuNet Alliance, and to support their development:

- Importance to collaborate with existing communication network providers in each country with the objective of reducing the Digital Divide:

- Highlight each country's individual problems and find possible ways forward, recognising that Internet policy varies from country-to-country. In this regard, it is important to establish contact with decision makers in each country;

- Work with the ICT communities in individual countries on required applications;

- An eGY-Africa representative will be useful at the forthcoming General Assembly of African Union on the ICT problem in Africa through the United Nations resources of Science and Technology of the African Union (AU) Commission.

The participants proposed also:

- Contact with the URSI (International Union of Radio Science) regional offices for a possible involvement for solving the communication problems confronting African scientists.
- An increase in the involvement of ICTP (The Abdus Salam International Centre of Theoretical Physics) in capacity building and the use and management of systems.

- An analysis of the way the ICT development was made possible in Latin America and South Africa.

- eGY-Africa has proposed the creation of a small group in each African country in order to make the case for better Internet connectivity and influence the implementation of NRENs and RENs. Representatives of those groups could be the ambassadors to create ties with advanced countries.

- Appointment, by African countries, of scientific attaches, just like we presently have military attaches and cultural attaches, in the major developing countries. The inspiration is to get eGY-Africa proposals on bridging the Digital Divide to policy makers of these countries, at the highest bilateral level.

\subsection{PingER}

The PingER project [Matthews and Cottrell, 2000] provides active end-to-end monitoring of worldwide Internet performance going back over a decade. The measurements are made between monitoring hosts and remote hosts, using the ubiquitous ping(see http://en.wikipedia.org/wiki/Ping) facility. The measurements include round trip time (RTT), loss, jitter, and derived throughput(see http://www.slac.stanford.edu/comp/net/wan-mon/tutorial.html\#derive). Currently, PingER monitors over 165 sites in 50 African countries, which, between them, contain over $98 \%$ of Africa's population. The African countries that are not currently monitored are Chad, Comoros, Equatorial Guinea, Sao Tome \& Principe, and Western Sahara. There are monitoring hosts in Algeria, Burkina Faso, South Africa, and Zambia.

A map of the minimum RTT measured from a monitoring host at the SLAC National Accelerator Laboratory near San Francisco in the US to hosts in African countries is shown in Figure 4. The minimum RTT is typically seen when there is no network congestion. On long distance links it provides an indication of the length of the path travelled between the hosts. For links connected via geo-stationary satellites (GEOS) the minimum RTT is $<450 \mathrm{msec}$. Thus African countries whose hosts are connected by GEOS are seen in red. This was particularly true for Central and Eastern African countries. The North African countries were connected to Mediterranean undersea cables. On the West coast: Angola, Benin, Cameroon, Cote d'Ivoire, Gabon, Ghana, Nigeria, and Senegal all have landing points for the SAT3/WASC/SAFE(see/http://en.wikipedia.org/wiki/SAT3/WASC_\%28cable_system\%29) undersea cable. In addition there were inland terrestrial links to Burkina Faso, Mali, Mauritania, Niger, between Egypt and Sudan, and between South Africa and Botswana, Namibia and Tanzania.

One can derive the TCP (Transmission Control Protocol) throughput from the measured loss and RTT, using 


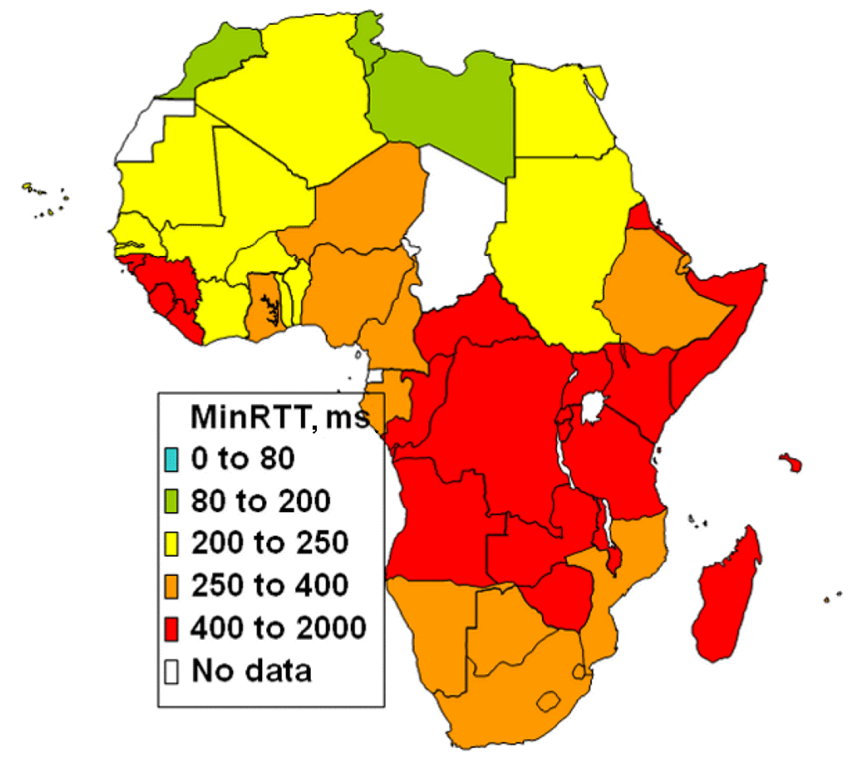

Figure 4. Minimum Round Trip Time measured from SLAC to African countries in July 2009.

the Mathis formula [Mathis et. al, 1997]. Figure 5 shows a map of derived throughput to Africa. Since the derived TCP throughput is inversely proportional to the RTT, the poor performance of Central and Eastern Africa is understandable. It can also be observed that Northern Africa and South Africa have better performance.

Figure 6 shows the average monthly derived TCP throughput by region as a function of time for the last decade. The data are measured from the USA. The data to the US and Canada are not shown, since the short RTT between the monitoring and remote hosts due to close proximity distorts the results. The lines are exponential fits to the individual data points for each region, which make the trends clearer. The orange line with dots shows a $30 \%$ improvement per year, or a factor of 10-improvement in 10 years. It can be seen that: E. Asia and Australasia have pretty much caught up with Europe; Latin America, Russia, the Middle East and S.E. Asia are catching up; S. Asia is keeping up; Central Asia and Africa are falling further behind. Extrapolation of the current performance back in time shows that: Russia, Latin America and the Middle East are about 5 years behind Europe; S.E. Asia is about 6 years behind; S. Asia is 9 years behind; Central Asia is 12 years behind, Africa is 16 years behind and its throughput is 20 times worse than, say, Europe's. The thick horizontal and vertical green lines are to assist in visualizing the extrapolation for Africa. Africa's rate of improvement is about $10 \%$ per year, or a factor of 2.5 in 10 years. This compares to regions such as E. Asia, Australasia, Russia, the Middle East and S. E. Asia that are improving by $30 \%$ per year, or a factor of 10 in 10 years. Unless something dramatic happens, in 10 years time Africa's performance will be $\sim 150$ times worse than developed regions.

At the start of 2009, the only submarine fibre optics cable between Sub-Saharan Africa and Europe was the SAT3/

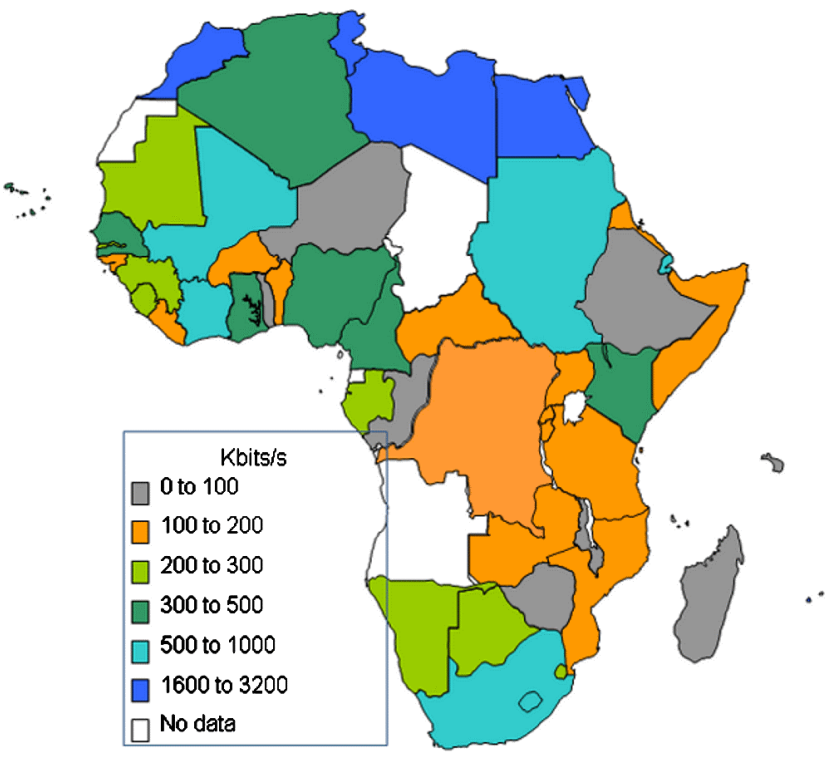

Figure 5. Derived TCP throughput seen from SLAC to African countries Jan - Aug 2009.

WASC/SAFE cable along the West African coast. There was no such fibre for the East coast of Africa. The fibre prices in $\$ /$ Mbits/s for access to this cable are very high since it is owned by a monopoly. With the 2010 Soccer World Cup (see http://www.fifa.com/worldcup/index.html) in South Africa rapidly approaching, there are now many major projects to install more submarine fibre cables serving Africa. A map showing the various cables is seen in Figure 7 The map is kept current by Steve Song and is available( See http://manypossibilities.net/african-undersea-cables/) on the Internet together with more details on the completion dates, ownership, capacity etc.

The Seacom (see http://www.seacom.mu/index2.asp) undersea fibre optics cable, plugging East Africa into the high

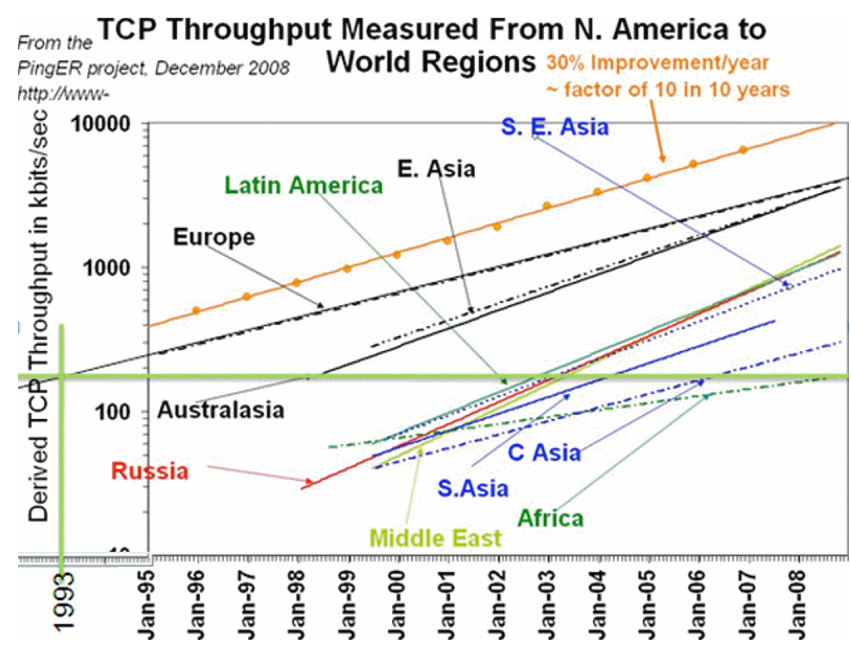

Figure 6. Derived TCP throughput for regions of the world measured from the USA. 


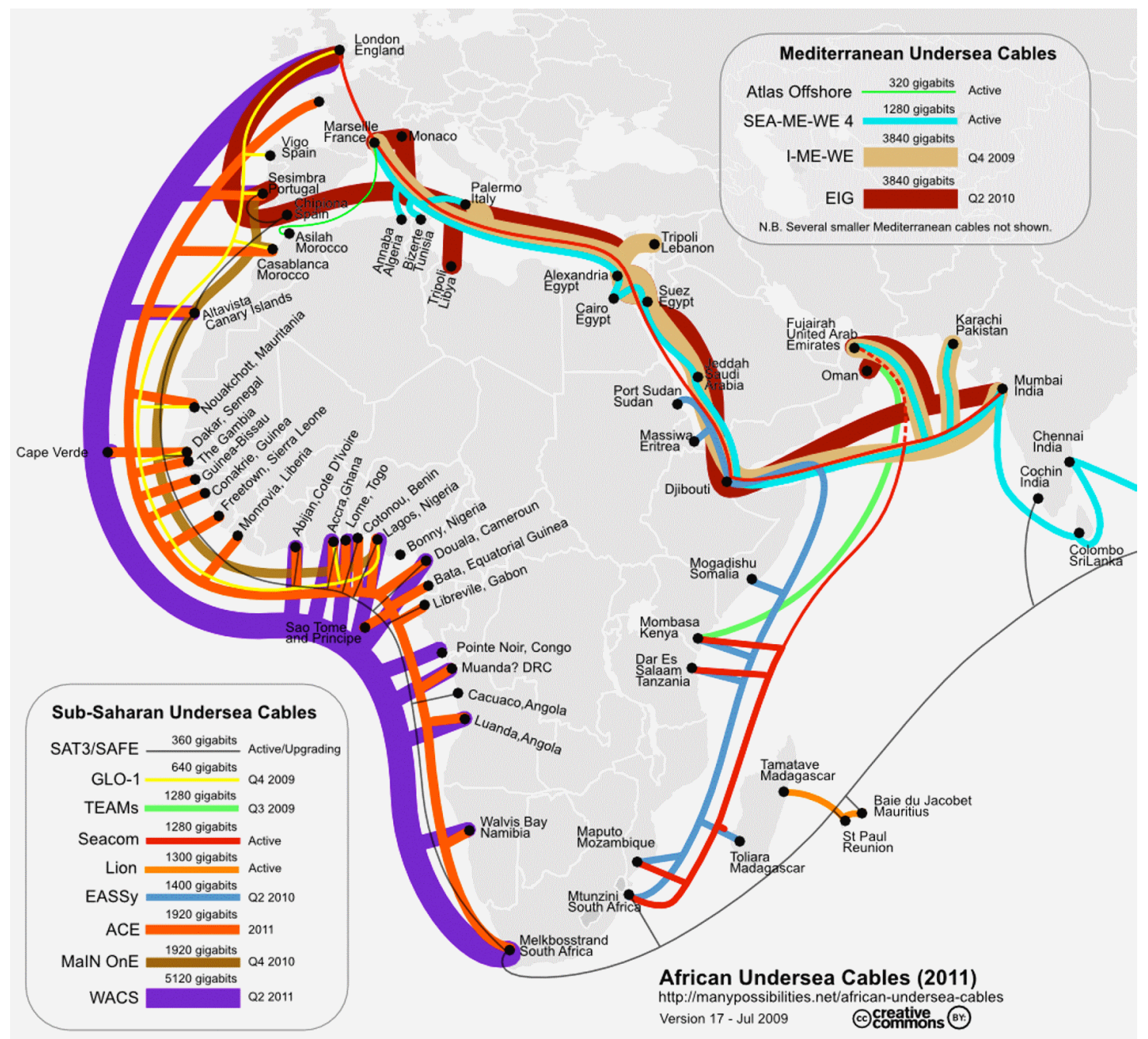

Figure 7. Submarine cable projects for Africa to be completed by 2011.

speed Internet, went live on Thursday July 23, 2009, as reported by the BBC (see http://news.bbc.co.uk/2/hi/africa/ 8165077.stm) and CNN (see http://edition.cnn.com/2009/ TECH/07/22/seacom.on/index.html). Such a cable enables dramatically reducing the Round Trip Times (RTT) from $<450 \mathrm{~ms}$ for a geostationary satellite, down to $200-350 \mathrm{~ms}$ (seen from N. America) by using shorter distance terrestrial routes. Increasing the capacity should also reduce the congestion and thus the losses and jitter. By providing competition, it has also already successfully reduced SAT3/WASC/ SAFE prices by a factor of two (van der Merwe, Christy (July 19, 2009). Seacom to boost capacity, but prices won't drop overnight. Engineering News.).

The impact of the Seacom cable is illustrated by the dramatic reductions in RTT before and after the switch from GEOS to terrestrial links starting after the Seacom cable went live on July 23, 2009. These are observed from Europe and the U.S. by PingER between June and October of 2009, for various hosts in South Africa, Kenya, Rwanda (via Uganda) and Uganda (via Kenya),. An example is the RTT to elearning.braeburn.ac.ke shown in Figure 8. On August 3 at around 19:00 hours as seen from SLAC, the median RTT to elearning.braeburn.ac.ke dropped from about $750 \mathrm{~ms}$ to about $400 \mathrm{~ms}$. The traceroute from SLAC to Braeburn goes via ESnet to Sunnyvale, crosses to Teleglobe, and then to GlobeInternet TATA communications to get to London. In Kenya, one of the nodes is Access Kenya which is associated with Seacom (see: http://www.accesskenya.com/).

At the time of writing, October 2009, by no means all hosts monitored in South Africa, Kenya, Rwanda and Uganda were connected by terrestrial links. In Kenya, five of the six hosts monitored have terrestrial connections, in Rwanda one of three, in Uganda one of three, and in South Africa the only university to be currently connected to Seacom is the Durban University of Technology. In South Africa the rest are waiting for the development of the national SANREN (see http://en.wikipedia.org/wiki/SANReN) backbone, later in 2009 (Private communication, Duncan Martin CEO of TENET, August 2009.). We also anticipate that hosts in other East African countries will connect to terrestrial links. These include Zambia via Namibia (see http://www.itnewsafrica. $\operatorname{com} / ? \mathrm{p}=2916$ ). In addition, in the last year, hosts such 


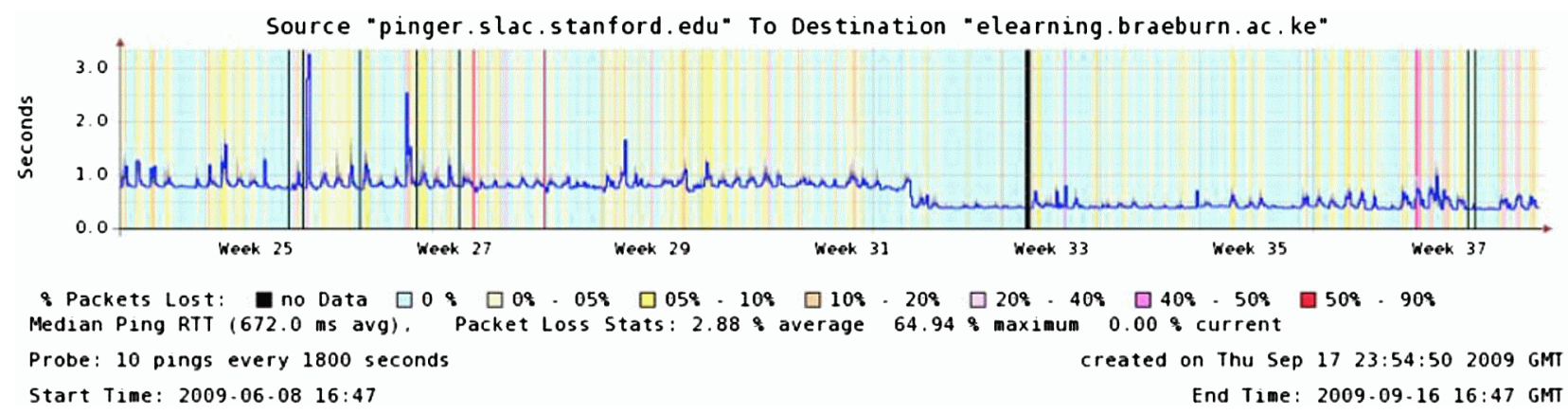

Figure 8. Time series of median RTT between SLAC and a host in Kenya. The background shading shows the losses, the solid blue line the median RTT and the gray shading shows the ranges of RTT measured. The black section indicates the host was unreachable.

as www.novagest.co.ao in Angola, www.haramaya.edu.et in Ethiopia and others in Namibia have connected to a terrestrial link (in the case of Namibia passing via South Africa).

Extending the deployment of the terrestrial links to areas where fibre connections are not available (e.g., rural areas) is a challenging task. In this context the main contenders appear to be:

- Wireless - microwave, cellphone towers, WiMax, etc.

- Low Earth Orbiting Satellites, for example, Google has signed up with Liberty Global and HSBC in a bid to launch 16 such satellites (see http://gigaom.com/ 2008/09/09/google-invests-in-satellite-based-internetstartup/) to bring high-speed internet access to Africa by the end of 2010 , and

- Weather balloons (see http://www.internetevolution. com/author.asp?section_id=694\&doc_id=178131\&).

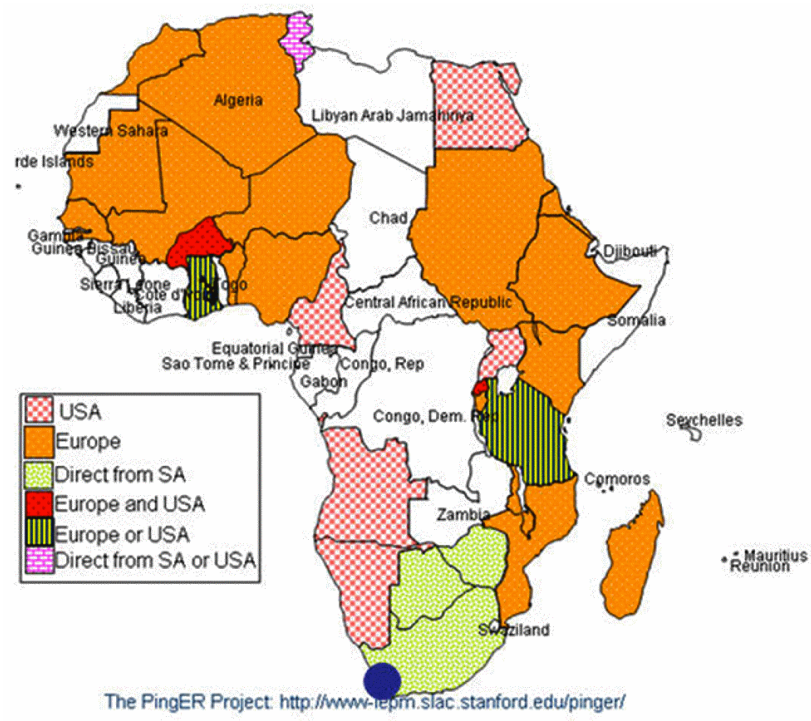

Figure 9. Routing to African countries as seen from Africa in 2005 .
The presence of Internet Exchange Points (IXPs) is important since it reduces the use of intercontinental providers between African countries. We studied the state of direct connections between African countries by measuring the trace routes within Africa. Figure 9 and Figure show the routes taken from South Africa to other African countries in September 2005 and August 2009, respectively. In Figure 10, countries which were only accessible by satellite have horizontal shading lines.

In September 2005, most traffic from South Africa to the rest of Africa took costly international links (e.g. via Europe and/or the USA), only Botswana and Zimbabwe had direct routes. The situation has improved recently as direct routes from South Africa to Mozambique and Namibia were added. Similarly, connections from Burkina Faso in August 2009 (not shown here) were direct to only Senegal, Mali, and Benin. Most other countries were reached by intercontinental connections via Europe, followed by many that go via Europe and N. America. Somalia was reached via Europe,

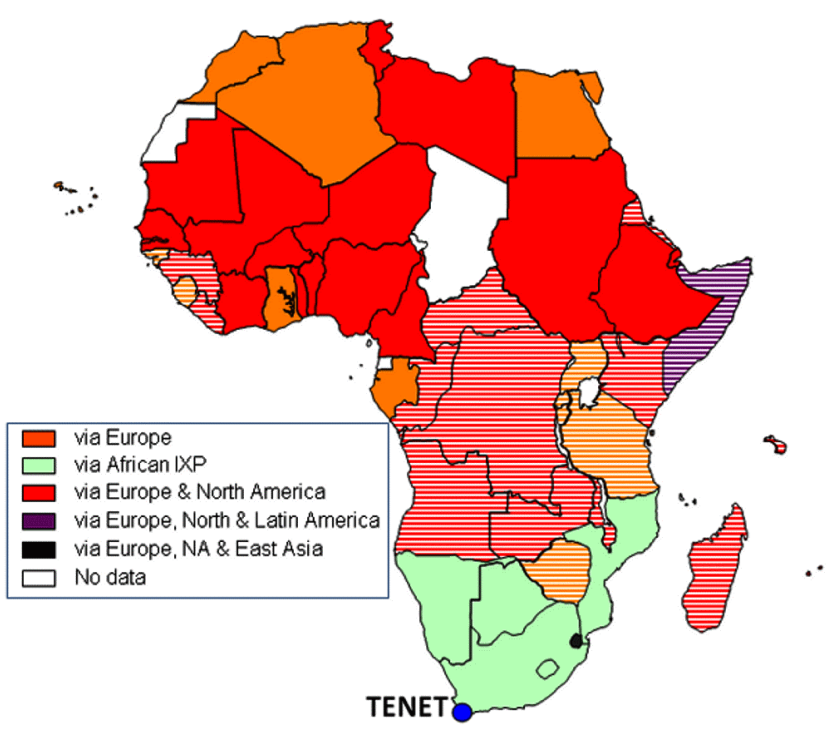

Figure 10. Routing to African countries as seen from Africa in 2009 . 
N. and S. America. Burundi was reached via Europe, N. America, and E. Asia.

According to the Mathis formula the standard TCP throughput is inversely proportional to the RTT times the sqrt(loss). Thus, dropping the RTTs by typically a factor of 2 or more and also reducing congestion and losses should increase throughput performance by over a factor of 2 . The hope is thus that the new fibres will lead to dramatic performance improvements that in turn will enable to start to catch up with the rest of the world..

\subsection{NREN Projects}

In the past, Sub-Saharan Africa has had expensive and poor Internet connectivity with heavy use of expensive geostationary satellite connections to the outside world. In 2004, for example, African universities paid 50 times what their US counterparts paid in $\$ /$ Mbps (see Enhancing Research and Education Connectivity in Africa, by Robert Hawkins, the World Bank). In addition, as seen above, much of the traffic between countries makes use of expensive international links via Europe and the U.S. rather than more direct connections. The main reasons behind this dire situation are lack of competition, costly technologies, and oppressive regulatory environments.

In order to address this problem and promote the development of NRENs, there is a need to build up bargaining power (e.g., via the Bandwidth Consortium (see http://www.bandwidthconsortium.org/), which is supported by the Partnership for Higher Education in Africa - PHEA); and, thence, to sensitize and influence policy and decision makers. These needs are beginning to be met by collaboration at national, regional, continental, and international levels, and emerging movements to create NRENs in SubSaharan Africa [Barry et al. 2008. Not only do these provide increased bargaining power for their member institutions but also direct connections between autonomous Internet administrations (peering) such as NRENs will enable more direct transit of Internet traffic between countries. These NRENs, in turn, for example, are peering with the GEANT network in Europe through consortiums such as the Ubuntunet Alliance (see http://www.ubuntunet.net/).

As can be seen in Figure 11, NRENs in Africa can be categorized into established (functioning), new (formally formed, but without an infrastructure in place), and emerging NRENs (ongoing establishment process). Active NRENs are essentially established in Northern, Southern and Eastern Africa. Well-established NRENs include: TENET/SAREN (South Africa), KENET (Kenya), MAREN (Malawi), EUN (Egypt), MARWAN (Morocco), RNU (Tunisia), CERIST (Algeria), and SUIN (Sudan).

Most of the initiatives for new NRENs are from the Ubuntunet alliance and include: Eb@le (RDC), MoRENet (Mozambique), RENU (Uganda), RwNet (Rwanda), and TERNET (Tanzania).

Emerging initiatives include: ZAMREN (Zambia); NAMREN (Namibia); NgREN (Nigeria) - there is a commitment of tens of university Vice Presidents to have it established

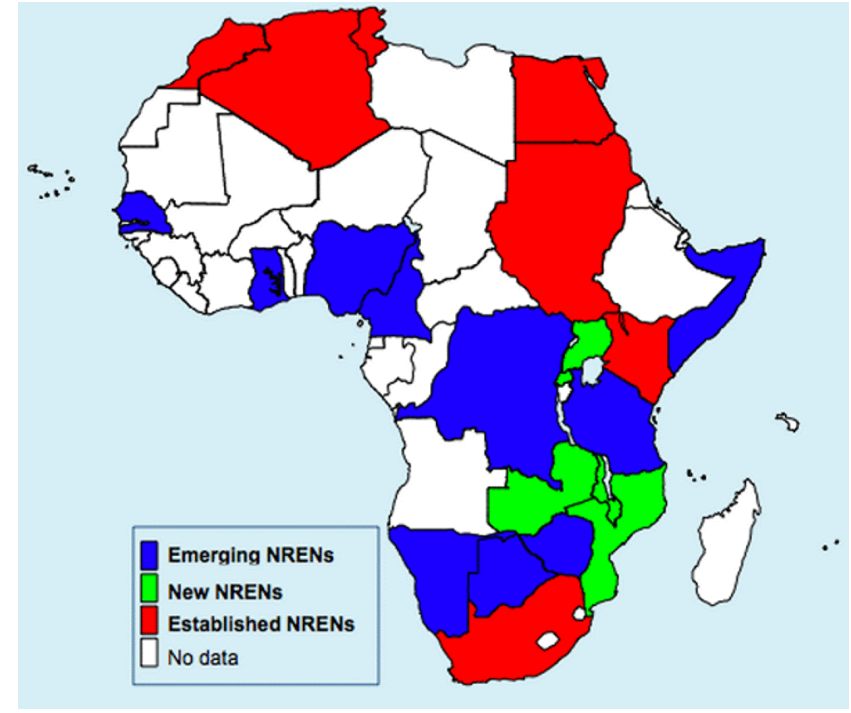

Figure 11. Map showing the state of NRENs in Africa [Barry, 2008.

by end of 2008; GARNET (Ghana) - there is a policy dialogue ongoing with two working groups handling policy and architecture issues; Cameroon NREN - the Reseau Interuniversitaire du Cameroun or RIC is a project aiming at linking 6 Cameroonian public universities to share bandwidth through Very Small Aperture Terminal (VSAT) links and has the commitment of government. A preparatory mission has been carried out in July 2009, and a national policy dialogue meeting on the establishment of a Cameroonian NREN (initiated by the AAU) is planned for December 2009; RENER (Senegal) - there is an ongoing policy dialogue with a meeting held in July 2009, where the stakeholders committed to establish the Senegalese NREN by 2010; Ivory Coast - where there is an ongoing policy dialogue despite the difficult political situation.

Other regional initiatives include:

- The Africa:EUMEDConnect project funded by the European Union. It links Mediterranean African countries with Europe through GEANT in addition to direct links from individual countries to GEANT. There is a will to move EUMEDConnect to provide interconnection between the countries.

- UbuntuNet is an alliance of several Southern and Eastern African NRENs aiming to interconnect and share bandwidth. The UbuntuNet alliance has the strong commitment of its members under difficult regulatory environments. However, with the new developments in the field of fibre infrastructure (SEACOM, TEAMS, and EASsy to come), it can be expected that regional research and educational networks will dramatically develop in East and Southern Africa in the months to come. The UbuntuNet Alliance has been connected to GEANT since January 2008 through a 1 Gbps link from South Africa to England.

- Regional initiative for Western and Central Africa: 
since 2006, there is there is an initiative aiming at establishing a regional research and education network for West and Central Africa (WACREN). Consultations have been underway since then, and it is expected that a substantial progress will be made at the consultative meeting of stakeholders which will be held in Accra in November 2009.

Finally, there is a large set of organisations that are enablers and supporters of the African NREN community; with new developments in terms of availability of infrastructure, new environments that see more competition and the large policy dialogue at national and regional levels, one can expect dramatic positive developments in the African research and education networking scene in the next couple of months and years.

\section{Scientific Collaborations}

\subsection{Context}

New high-level technologies are used and disseminated readily through research and education. The role of the scientific collaboration in regard to the Internet and ICT improvement is twofold:

- to foster user communities to experiment and disseminate new high-level technologies, and to interact with the providers in order to fulfil the local requirements;

- to strengthen the collaboration among African teams within the framework of international programmes (see the recommendations in section 2.3 above). International programmes provide data, access to expertise, and provide scientific opportunities via the Internet.

Below, we describe a selection of collaborative projects in different geophysical fields that involve a large number of African partners and organisations, and concern subSaharan Africa.

\subsection{African Geospace Society}

One of the spin-offs of eGY/IHY was the establishment of the African Geospace Society. The AGS is a dynamic, innovative, and interdisciplinary scientific association of African scientists undertaking research about the Earth and its space environment for the benefit of mankind in general and African nations in particular. The fields of relevance to the Society are: Solid Earth Science; Atmospheric Science; Ocean Science; Astronomy and Planetary Science; Solar and Terrestrial Science; and Hydrological Science.

The secretariat of the Society is located in the United Nations's African Regional Center for Space Science and Technology Education (ARCSSTEE), Obafemi Awolowo University Campus, Ile-Ife, Nigeria. Establishment of the AGS demonstrates that scientific research and administration can be effectively carried out by Africans within the region, in cooperation with other sister regional bodies, in order to achieve sustainable person-power development and effective utilization of human resources towards scientific development of the region. Like every other regional bodies, the AGS organises activities capable of raising the level of scientific research and building human capacity in the African region. Programs such as symposia, general assemblies and capacity building workshops are already scheduled in the calendar of activities of the AGS.

The AGS is democratically structured, with a standard constitution available on the Society's website. Membership is not restricted to individuals of African origin and is open to persons who are professionally associated with studies of Earth and Space sciences. The AGS is at present forging strong partnership with other regional and academic societies of equivalent objectives, including the American Geophysical Union (AGU), the Asia-Oceania Geosciences Society (AOGS), the European Geosciences Union (EGU), the International Union of Geodesy \& Geophysics (IUGG), the Royal Astronomical Society, the International Union of Radio Sciences (URSI), and the World Meteorological Office (WMO).

The eGY and the IHY, which are international scientific cooperation commemorating 50 years since the International Geophysical Year (IGY), coordinated the organisation of several workshops, symposia and capacity building workshops in Africa. Gains and achievements of the eGY and the IHY in Africa include the following: knowledge and technological transfer, positive collaboration, availability of research facilities for internationally competitive research, publication of scholarly articles, windows of postgraduate opportunities, control of brain drain, development of research in Basic Space Science, capacity building, bridge between North and South, and fostering of strong intracontinental partnerships amongst African scientists. These gains can be sustained by the AGS through planned activities.

\subsection{International Geophysical Research Group Europe-Africa}

At the International Association of Geomagnetism and Aeronomy Scientific Assembly, held in 1987 in Vancouver, the Inter-Divisional Commission on Developing Countries (ICDC) requested intensification of studies of the Equatorial Electrojet studies within the framework of the International Equatorial Electrojet Year (IEEY). After the IGY and the programs that followed it, the IEEY was the first planetary experiment to be handled largely by scientists from developing countries.

Many instruments were deployed over West Africa to study the equatorial region during the observing campaign, 1992-1994. Subsequently, in 1995, the International Geophysical Research Group Europe Africa (IGRGEA) was launched to follow-up on the research initiated during IEEY. Since January 2005, the Institute of Geophysics in Hanoi has been part of the IGRGEA. Since 2006, IGRGEA has become 
involved in the International Heliophysical Year project over Africa. This network of scientists from different countries is mainly working now on "Integrated studies in the Sun-Earth System" and, more particularly, on the physical processes associated to electrodynamics and magnetic phenomena.

Before 2005, the African scientists of IGRGEA produced many publications in international journals, even if there was little, or no Internet access [Amory-Mazaudier et al., 2005. The work was adapted to the local facilities, data were recorded on CDs, and the African scientists worked in their own countries. This success was due to the development of new management in North-South cooperation based on sharing practices and ethics rules [Amory-Mazaudier, 2002].

In 1992, at the beginning of the IEEY project, the IGRGEA was composed of 20 scientists, from Algeria, Benin, Ivory Coast, England, France, Spain, and Senegal. Today, more than 200 scientists are working within or are connecting to IGRGEA, from Algeria, Benin, Burkina Faso, Congo Brazzaville, Ivory Coast, Egypt, England, France, India, Japon, Niger, RDC, Rwanda, Spain, Senegal, USA, Vietnam. $17 \mathrm{PhDs}$ have been defended and 15 are in progress.

The IGRGEA network of scientists constitutes a user community to support and promote the deployment of the Internet and new ICT technologies that are required to develop their scientific work. The IGRGEA participates to the follow-on of IHY, the International Space Weather Initiative (ISWI).

\subsection{The International Heliophysical Year (IHY)}

The IHY project (http://ihy2007.org). was suggested in 2001 to celebrate the 50th anniversary of the International Geophysical Year (IGY). The objectives of the IHY [Harrison et al., 2005 are:

- to understand the processes and drivers that affect the terrestrial environment and climate;

- to provide a global study of the Sun-Heliosphere system outward to the heliopause;

- to foster international cooperation in space science now and in the future;

- to communicate the unique scientific results of the IHY to the scientific community and to the public.

The IHY promoted the participation by developing nations in international global studies of the Sun-Earth System. It is based on the tripod concept: instruments, observations and education [Davila et al., 2007] Kitamura et al., 2007. IHY involved thousands of scientists from 71 countries and more than 200 observatories.

Low-cost scientific instruments were deployed all over the world (GPS stations, VLF receivers, magnetometers or others), but particularly in Africa. IHY organized two workshops, first in 2007 in Ethiopia, with a large participation of African scientists (63 African scientists from 19 African countries out of 103 participants); and second in Zambia in
2009, with 80 African scientists from 19 countries out of 115 participants.

IHY led to the development of new research teams on Space Science' in Africa and, as a consequence, the need for good Internet connectivity. Due to the results and successes of IHY a follow-on project, the International Space Weather Initiative (ISWI) for years 2010-2012 -was adopted in April 2009 as a United Nations (UN) supported program during the session of the Science and Technical Subcommittee of the UN Committee of Peaceful Use of the Outer Space (COPUOS). Three workshops are already planned in 2010 in Luxor (Egypt), in 2011 in Abuja (Nigeria) and in 2012 Galapagos (Ecuador).

\subsection{The African Monsoon Multi-disciplinary Analysis (AMMA)}

The monsoon season has a large socio-economic impact, particular in West Africa. It is important for agriculture to be able to predict precisely its beginning. The African Monsoon Multi-disciplinary Analysis (AMMA - http://www. amma-eu.org) program operated a field experiment consisting of periods with different observing strategies according to the topic under study and involving the relevant instruments deployed in this region. AMMA was coordinated by MeteoFrance, and involved a large number of partners from Europe, Africa, and America. In sub-Saharan countries, AMMANET was formed as a network of African scientists, from different countries (Benin, Burkina Faso, Cameroon, Ghana, Ivory Coast, Niger, Nigeria and Senegal) and various disciplines (hydrology, meteorology, pollution, and so forth). African organisations such as ACMAD (African Centre of Meteorological Applications for Development http//www.acmad.ne), AGRHYMET (Specialized institute for permanent Interstate Committee for Drought Control in Sahel), and ASECNA (Civil Aviation in Africa and Madagascar) that undertake radio-soundings also participated in AMMA.

The data are the core of the project. The poor performance of the Internet and its high cost have been obstacles for achieving real-time transfer of all the data within Africa and from Africa to Europe. The transfer of knowledge and expertise has been carried out via working groups, preparation of PhDs, schools and workshops.

The main objectives of AMMA concern weather and climate prediction, but the results have an impact on the management of water resources, health, food and socio-economic sectors.

\subsection{Geoscience Information in Africa (GIRAF)}

National earth science authorities worldwide have seen their businesses revolutionised through the advent of ICT. In many countries, a large part of their business is the provision of geoscientific information to users with the above wide range of needs for basic earth science data related to national territories. Traditionally, this has been achieved 
through the publication of paper maps and reports. These can now be replaced by more efficient and effective publication via the Internet and maps may be exported in digital formats directly into widely used GIS systems.

In addition to the above uses, most African countries see sustainable development of their mineral resources (solid minerals as well as oil and gas) as an important element in a viable economic future. Such developments require inward investment in the exploration process which, in turn, should be guided by the best available geoscientific information for the area. This has been supported by international aid agencies (World Bank, EU, etc) through huge investments (tens of millions of dollars) in geological reconnaissance programmes using the latest airborne technologies. The following step is the attraction of foreign investment into the exploration process, steered by corporate interpretations of the new and pre-existing geological knowledge. The lack of ICT infrastructure in Africa has, so far, led to national geological surveys being singularly ill-equipped to benefit from the ICT revolution and even their latest geological databases are now perceived as inaccessible in a world attuned to rapid information access via the Internet. Worse, the performance of many national organisations is still assessed or financed based on sales of outdated paper maps. Some even rely on such sales as an important contribution to their annual running costs.

GIRAF (Geoscience InfoRmation in Africa) is an initiative for promoting geoscience information usage across Africa in an ICT-aware manner. Between the 16th and 20th March 2009, 97 participants from 26 African nations, plus four European countries, and representatives from UNESCO, ICSU and IUGS-CGI, held a workshop at the Namibian Geological Survey in Windhoek. This GIRAF 2009 workshop, organised by the Federal Institute for Geosciences and Natural Resources (BGR) and the Geological Survey of Namibia (GSN), was held at the Namibian Ministry for Mines and Energy. It was mainly financed by the German Federal Ministry for Economic Cooperation and Development (BMZ), supported by the IUGS Commission for the Management and Application of Geoscience Information (CGI). A prime objective was to set up a pan-African network for exchanging knowledge about geoscience information.

The five aims of the GIRAF2009 workshop were:

- to bring together relevant African authorities, national experts and stakeholders in geoscience information;

- to initiate the building of a pan-African geoscience information knowledge network to exchange and share geoscience information knowledge and best practice;

- to integrate the authorities, national experts and experts across Africa into global geoinformation initiatives;

- to develop a strategic plan for Africa's future in geoscience information;

- to make Africa a more active part of the international geoscience information community.
The programme for the GIRAF2009 workshop was designed to explore each of these aspects to improve the way geoscience information contributes to improve the health and prosperity of the people in Africa. The very tangible outcome of a hardworking but fruitful week was the unanimous endorsement of a series of fifteen practical recommendations - the GIRAF Strategy and Agreement.

Further information on GIRAF and its Strategy and Agreement is at: www.GIRAF2009.org. The organisers would be most pleased to hear from African nations who were not able to attend the GIRAF 2009 Workshop.

\section{Perspectives}

The needs for ICT resources have already been identified in many sectors - e.g., in the fields of human and animal health, environment, natural disaster prediction and business. However for the scientific communities in Africa working on a common area, such as the geosciences, it is easier to collaborate with Northern hemisphere countries than with neighbouring African countries, even if located in the same region, due to a lack of reliable Internet connectivity. While waiting for substantial improvements in the Internet and cyber-Infrastructure, the African scientists and engineers want to learn how to deal with new technologies and to experiment with them, at least locally. The ultimate goal is to employ the new technologies, such as the Grid, first at a national level, then at regional level, and finally at the continental level, in like manner to the ones existing in Europe, Mediterranean Area, and Latin America.

In North-Africa, Algeria, Egypt, Morocco, Syria and Tunisia participated to the FP6 European project, EUMEDGRID. A set of pilot applications of regional interest, covering several application domains, including: Archaeology, Hydrology, Physics, Biology, Engineering, Robotics and Cognitive Sciences, were deployed on the EUMEDGRID infrastructure. EUMEDGRID acted as a trigger towards supporting the creation of National Grid Initiatives for the creation of e-Infrastructures in Algeria, Egypt, Morocco and Tunisia. At the end of the project, in 2008, the pilot grid infrastructure included 25 sites distributed across 13 countries, with all relevant grid services up and running.

In 2006, UNESCO and Hewlett-Packard launched an ICT based project to counter the brain drain in Africa. This project concerns five universities, located in Algeria, Ghana, Nigeria, Senegal and Zimbabwe. This project was first to equip the computing centers, to carry out training on the machine (cluster) management, and implement a local Grid. This project has been working in collaboration with teams involved in the European Grid project, EGEE. In Senegal, the Cheikh Anta DIOP University in Dakar (UCAD) has been connected since 2007 to the European Grid network via the EGEE project. In South Africa, two schools on Grids were held with the participants from different African countries. A Grid called SAGRID is in preparation. Users and site administrators have acquiring the technical skills and know-how necessary to deploy and operate a national production grid infrastructure, with the help of EGEE and 
related partners. In Cameroon, several PhDs included Grid applications. In Republic Democratic of Congo, the University of Kinshasa has started making tests on Grid.

The other important point concerns access to data. Most African data are stored outside Africa and African scientists need access to the vast stores of data (and other services) that are available through the World Data Centres and other sources overseas. Access to basic databases and services (for analysis, visualisation, and so forth) is only possible through a good Internet connection. An example of available resources is SPIDR (see http://spidr.ngdc.noaa.gov/spidr/) (Space Physics Interactive Data Resource), a server of databases developed by NOAA (the National Oceanic and Atmospheric Administration) and GCRAS (Geophysical Center of the Russian Academy of Science) [Zhizhin et al., 2009. SPIDR includes climatological databases, it is updated with new data regularly. It is planned to be the repository for GPS African data, and it offers the possibility of adding other databases. A SPIDR server is installed in South Africa and other installations are planned. These provided a good opportunity for the students and staff to carry out research. The African Union and the European Union have launched an international cooperation programme called AMESD (see http://www.amesd.org/) (African Monitoring of the Environment for Sustainable Development), for the implementation of an efficient system for environmental surveys in order to improve the management of agriculture, ocean and river resources. In connection with AMESD and other African projects, GEONETCast (see http://earthobservations.org/documents/committees/adc/ 200905_10thADC/GEONETCast\%20ADC10\%20Stresa\%20 May\%2009.pdf) for and by Developing countries, DevCoCast (see http;//www.devcocast.eu), provides reliable and continuous access to environmental information and data all over the world. Training workshops are organized in different African countries.

\section{Conclusions}

Research and education are essential ingredients for national advancement worldwide. Countries that invest in research and education are conspicuously more successful in the long-term than those that don't. As we move into the modern information era, this translates into a need for ready and effective access to the Internet and information highways by those engaged in research and education. Countries in Africa, as in other parts of the world, recognize this reality and are developing cyber-information networks (NRENs) to meet the information and service delivery needs of their research and education sectors. But, as the PingER project demonstrates, African countries, in general, have poorer Internet connectivity and are advancing more slowly than in other parts of the world - i.e., the so-called Digital Divide for Africa is growing. eGY-Africa is taking steps to address this problem by mobilizing opinion in Africa and internationally, accumulating information that can be used to argue the case for investing in Internet and NREN capability, and bringing together different groups in Africa and elsewhere that share the goal of reducing this Digital Divide.

\section{References}

Amory-Mazaudier, C. (2002), Ideas and Research programmes, Earth's environment International cooperation, Book of History of geomagnetism and aeronomy, Solar varibility and Geomagnetism, collected and edited by W. Schroder, B, Science edition AKGGKP, Bremen-Ronnebeck, Postdam.

Amory-Mazaudier, C., et.al. (2005), On Equatorial geophysics studies : The IGRGEA results during the last decade, Journal of Atmosphere and Solar terrestrial Physics, 67(4), 301.

Barry, B. (2008), Research and educational networking in SubSaharan Africa-An update, Fall 2008 Internet2 Member Meeting, Internet2 Brd, New Orleans, USA.

Barry, B., V. Chukwuma, M. Petitdidier, Les Cottrell, C. Barton (2008), Digital Divide in Sub-Saharan Africa Universities: Recommendations and Monitoring, IST-Africa 2008 Conference Proceedings, P. Cunningham, M. Cunningham, (Eds), IIMC International Information Management Corporation, ISBN: 9781-905824-07-6.

Chukwuma, V., B. Rabiu, M. Petitdidier, Les Cottrell, C. Barton (2009), Digital Divide, eGY-Africa, and the way forward, $I H Y$ Africa/SCINDA 2009 Workshop, Livingstone, Zambia.

Davila, J., N. Gopalswamy, H. J. Haubold, B. Thompson (2007), International Heliophysical Year 2007, Basic Space Science initiatives, Science Direct, space policy, 33, 121.

Duncan, M. (2008), Research and educational networking in Sub-Saharan Africa-Infrastructure development, Fall 2008 Internet2 Member Meeting, Internet2 Brd, New Orleans, USA.

Harrison, R., A. Breen, B. Bromage, J. Davila (2005), International Heliophysical Year, Astronomy and Geophysics, 46(3), 27.

Kitamura, M., et al. (2007), The United Basis Space Science Initiative: The TRIPOD concept, Proceedings IAU Symposium 2007, International Astronomical Union, Porlamar, Venezuela.

Mathis, M., T. Semke, T. Ott (1997), The macroscopic behavior of the TCP congestion avoidance algorithm, Computer Communication Review, 27(3),

Matthews, W., R. L. Cottrell (2000), The PingER Project: Active Internet Performance Monitoring for the HENP Community, IEEE Communications Magazine, 38(5),

Tusubira, F. F. (2008), Creating the future of research and education networking in Africa, Fall 2008 Internet2 Member Meeting, Internet2 Brd, New Orleans, USA.

Zhizhin, M., E. Kihn, R. Redmon, D. Medvedev, D. Mishin (2009), Space Physics Interactive Data Resource-SPIDR, Earth Science Informatics, 2, 79. 


\section{Appendix. List of Acronyms}

\begin{tabular}{|c|c|}
\hline AAU & Association of African Universities \\
\hline $\mathrm{ACBF}$ & African Capacity Building Foundation \\
\hline ACMAD & African Centre of Meteorological Applications for development \\
\hline AfNOG & $\begin{array}{l}\text { Forum for the exchange of technical information, and aims to } \\
\text { promote discussion of implementation issues that require } \\
\text { community cooperation }\end{array}$ \\
\hline AfriNIC & $\begin{array}{l}\text { Regional Internet Registry that will allocates IP and AS } \\
\text { numbers in the African region }\end{array}$ \\
\hline AGS & African Geospace Society \\
\hline AMCOST & African Ministerial Council on Science and Technology \\
\hline AMMA & African Monsoon multidisciplinary Analysid \\
\hline ARAPKE & African Regional Action Plan on the Knowledge Economy \\
\hline ARCSSTEE & $\begin{array}{l}\text { UN's African Regional Center for Space Science and } \\
\text { Technology Education }\end{array}$ \\
\hline $\mathrm{AU}$ & African Union \\
\hline AUC & African Union Commission \\
\hline Cameroon REN & Emerging NREN initiative in Cameroon \\
\hline CERIST & Established NREN in Egypt \\
\hline CRASA & Communications Regulators' Association of Southern Africa \\
\hline DANTE & Delivery of Advanced Network Technology to Europe \\
\hline $\mathrm{DFN}$ & $\begin{array}{l}\text { Plans builds and operates advanced networks for research } \\
\text { and education }\end{array}$ \\
\hline Eb@le & New NREN proposed for RDC \\
\hline ECOWAS & Economic Community Of West African States \\
\hline EGEE & Enabling Grids for E-SciencE \\
\hline eGY & The Electronic Geophysical Year, 2007-2008 \\
\hline EU & European Union \\
\hline EUMEDGRID & Empowering eScience across the Mediternanean \\
\hline EUN & Established NREN in Egypt \\
\hline GARNET & Emerging NREN initiative in Ghana \\
\hline GARR & The Italian Academic and Research Network \\
\hline GCRAS & Geophysical Center of the Russian Academy of Science \\
\hline GEANT & $\begin{array}{l}\text { The fast and reliable communication infrastructure dedicated } \\
\text { to serving Europe's research and education community }\end{array}$ \\
\hline GEOS & Geostatioanry Satellite \\
\hline GIRAF & Geoscience Information in Africa \\
\hline GPS & Global Positioning System \\
\hline HENP & High Energy and Nuclear Physics \\
\hline IAGA & International Association of Geomagnetism and Aeronomy \\
\hline $\mathrm{ICDC}$ & Inter-Divisional on Developing Countries \\
\hline ICSU & The International Coluncil for Science \\
\hline IDRC & International Development Research Centre \\
\hline IGRGEA & International Geophysical Research Group Europe-Africa \\
\hline IHY & International Heliophysical Year \\
\hline IUGG & International Union of Geodesy and Geophysics \\
\hline KENET & Established NREN in Kenya \\
\hline MAREN & Established NREN in Malawi \\
\hline MARWAN & Established NREN in Egypt \\
\hline MoRENet & New NREN proposed for Mozambique \\
\hline NEPAD & New Partnership for Africa's Development \\
\hline NGO & Non-Governmental Organisation \\
\hline NgREN & Emerging NREN initiative in Nigeria \\
\hline NOAA & National Oceanic and Atmospheric Administration \\
\hline NREN & National Research and Education Network \\
\hline NSRC & Network Startup Resource Center \\
\hline PAREN & Promoting African Research and Education Networking \\
\hline
\end{tabular}

\begin{tabular}{l} 
http://www.aau.org \\
\hline http://www.acbf-pact.org \\
\hline http://www.acmad.ne/ \\
\hline http://www.afnog.org \\
http://www.afrinic.net \\
\hline http://www.arcsstee.org/ags.html \\
\hline http://www.nepadst.org/ \\
\hline http://www.amma-eu.org
\end{tabular}

http://www.arcsstee.org http://www.africa-union.org http://www.africa-union.org

http://www.crasa.org http://www.dante.net

http://www.dfn.de

http://www.ecowas.int http://www.eu-egee.org http://www.egy.org

http://www.eumedgrid.org http://www.eun.eg http://www.garnet.edu.gh http://www.garr.it http://www.gcras.ru

http://www.geant.net

http://www.GIRAF2009.org

http://www.iugg.org/IAGA

http://www.icsu.org

http://www.idrc.ca

http://Ihy2007.org

http://www.iugg.org

http://www.kenet.or.ke

http://www.malico.mw/maren/

http://www.marwan.net/

http://www.nepad.org

http://www.noaa.gov

http://en.wikipedia.org/wiki/National_research_and_education_network http://www.nsrc.org 


\section{List of Acronyms (Continued)}

\begin{tabular}{lll|} 
PHEA & Partnership for a higher Education in Africa & http://www.foundation-partnership.org \\
RENATER & French National Network of telecommunications for the & \\
technology, the education and the Research & http://www.renater.fr \\
RENER & Emerging NREN initiative in Senegal & \\
RENU & New NREN proposed for Uganda & http://www.cck.rnu.tn/ \\
RNU & Established NREN in Tunisia & \\
RTT & Round Trip Time (for PinGER) & \\
RwNet & New NREN in Rwanda & http://www.fas.org/spp/military/ \\
Scinda & The Scintillation Network Decision Aid & program/nssrm/initiatives/scinda.htm \\
SUIN & New NREN in Sudan & \\
TCP & Transmission Control Protocol & http://en.wikipedia.org/wiki/Transmission \\
\hline TENET/SAREN & Established NREN in South Africa & http://en.wikipedia.org/wiki/SANReN \\
TERNET & New NREN in Tanzania & http://www.ternet.or.tz/ \\
UNESCO & United Nations Educational, Scientific and Cultural & http://www.unesco.org \\
URSI & Organization & http://www.ursi.org \\
WATRA & The International Union of Radio Sciences & http://98.130.227.12/Index.aspx \\
ZAMREN & West Africa Telecommunications Regulators Assembly & \\
\hline
\end{tabular}

C. Amory-Mazaudier, Laboratoire de Physique des Plasmas, 4 Avenue de Neptune, 94107, Saint Maur des Fosses Cedex, France (christine.amory@lpp.polytechnique.fr)

B. Barry, Association of African Universities, P.O. Box 5744 Accra North, Ghana (barry@aau.org)

C. E. Barton, Research School of Earth Sciences, Australian National University, Canberra, ACT 0200, Australia (charles.barton@anu.edu.au)

V. Chukwuma, Department of Physics, Olabisi Onabanjo University, PO Box 351, Ago-Iwoye, Ogun State Nigeria (victorchukwuma@yahoo.com)

R. L. Cottrell, SLAC National Accelerator Laboratory, 2575 Sand Hill Road, Menlo Park, California 94025, USA (cottrell@slac.stanford.edu)
U. Kalim, School of Electrical Engineering and Computer Sciences (SEECS), Pakistani National University of Sciences and Technology (NUST), H12 Sector, Islamabad, Pakistan (kalim@slac.stanford.edu)

A. Mebrahtu, Physics Department, Mekelle University, Mekelle, Ethiopia (alemmeb@googlemail.com)

M. Petitdidier, Laboratoire d'Atmosphere, Milieux, Observations Spatiales, IPSL-10-12 Avenue de l'Europe, 78140 Velizy, France (monique.petitdidier@latmos.ipsl.fr)

B. Rabiu, Centre for Space Research and Applications, Federal University of Technology, Akure, Nigeria (tunderabiu@yahoo.com)

C. Reeves, Earthworks bv, Achterom 41a, 2611 PL Delft, The Netherlands (reeves.earth@planet.nl) 